\title{
Past and Future of in-vitro and in-vivo Animal Models for Diabetes: A Review
}

\author{
Hemlata Dewangan ${ }^{2}$, Raj Kumar Tiwari ${ }^{1}$, Vikas Sharma ${ }^{1}$, Shiv Shankar Shukla ${ }^{1}$, Trilochan Satapathy ${ }^{1}$, \\ Ravindra Pandey ${ }^{1 *}$
}

1'Department of Herbal Drug Development, Columbia Institute of Pharmacy, Raipur, Chattisgarh, INDIA.

${ }^{2}$ Post graduate Research scholar, Columbia Institute of Pharmacy, Raipur, Chattisgarh, INDIA.

\begin{abstract}
Diabetes mellitus is classified into two major types, Type 1 (Insulin Dependent Diabetes Mellitus) and Type 2 (Non-Insulin Dependent Diabetes Mellitus). In world about 90\% of diabetes patients are of Type 2 diabetes. There are various in-vivo and in-vitro methods available for the screening of new antidiabetic drugs. In-vivo models mainly uses chemical such as streptozotocin, alloxan etc. for the induction of diabetes where as in-vitro techniques, directly show its effect on cells which are responsible for induction of diabetes in human. In vitro techniques provide more accurate data and possible mechanism which are involved in diabetes disease. Now, a day's newer techniques such as diabetes induction with the help of viruses had been also introduced which are proving to be good tool in evaluation of antidiabetic drugs. This review could prove to be a good tool for the researchers who seek to do research on diabetes as it is providing vast resource about diabetic model under single umbrella.
\end{abstract}

Key words: Diabetes, in vivo, in vitro, STZ, Alloxan.

\section{INTRODUCTION}

Diabetes is considered as a severe health hitch being the third major cause of death all over the world. Type 2 diabetes mellitus (T2DM) is a global epidemic with an estimated worldwide prevalence of 6\% (246 million people) in 2007, and forecast to rise to $7.3 \%$ (380 million) by 2025 . Diabetes, if not treated, is conscientious for much harm affecting various organs in the body. ${ }^{1}$ Diabetes mellitus (DM) is a metabolic disorder resulting from a defect in insulin secretion and/or insulin action, which results in hyperglycemia with disturbances of carbohydrate, fat, and protein metabolism. ${ }^{2}$ It is a disease mainly resulting from idiosyncrasy of carbohydrate metabolism. It is mainly described by absolute (type I) or relative (type II) lack in insulin emission or receptor desensitization to insulin, ensuing in hyperglycemia. ${ }^{3}$ Diabetes mellitus is associated with oxidative stress induced micro- and macrovascular complications.
Long-term complications of diabetes mellitus involve almost all the vital organs such as heart, eyes, kidney, blood vessels, and nervous system. ${ }^{4}$ One therapeutic approach to treat diabetes is to retard the absorption of glucose via inhibition of enzymes, such as $\alpha$-glucosidase, in the digestive organs. ${ }^{5}$

Diabetes mellitus is classified into two major types, Type 1 (Insulin Dependent Diabetes Mellitus) and Type 2 (Non-Insulin Dependent Diabetes Mellitus). In world about $90 \%$ of diabetes patients are of Type 2 diabetes. ${ }^{6}$

The studies of diabetes in in-vivo and newer in vitro techniques are important for the development of acquaintance and clear indulgent of the pathology and pathogenesis, and to discover new therapy. Diabetic study on different animal models is therefore, significantly of use in biomedical research as they offer new insights to diabetes. $^{7}$
Submission Date: 05-01-2017; Revision Date: 10-05-2017; Accepted Date: 15-07-2017

DOI: 10.5530/ijper.51.4s.79 Correspondence: Dr. Ravindra Pandey, Department of Herbal Drug Development, Columbia Institute of Pharmacy, Raipur, Chattisgarh, INDIA.

Phone: 9826229321 E-mail: ravindra56@rediffmail.com 
Most of the animal models available are based on rodents because of their shorter generation intervals, small size, and monetary considerations. There are several experimental diabetes methods that include: diabetes on genetically modified animals, chemical and surgical. Screening of new drug requires an appropriate animal model and other environmental condition for treatment of diabetes. ${ }^{8}$

The major objective of the present review is to bring collectively all different in vivo models and in vitro methods under one plane so that it may be useful to researchers who are seeking their experimental work on diabetes.

\section{In-vivo studies}

\section{Diabetes induction with chemicals:}

The bulk of work available in the meadow of ethnopharmacology between 1995 and 2007 employed this model. Streptozotocin (STZ, 69\%) and alloxan (31\%) are by far the most frequently used drugs and this model has been useful for the study of multiple aspects of the disease. Both drugs wield their antidiabetic action when they are administered parenterally (intraperitoneally, intravenously, or subcutaneously). The required dose of these agents for inducing diabetes depends on the animal species, route of administration. ${ }^{\text {? }}$

\section{Streptozotocin model of diabetes mellitus}

Streptozotocin prevents the development of DNA in bacterial cells and mammalian cells. It acts on cytosine groups in bacteria, causing relapse and damage of DNA. ${ }^{10}$ The invasion of Streptozotocin in pancreatic cell is through a glucose transporter-GLUT2 and causes alkylation of DNA (Figure 1). STZ also persuade activation of poly adenosine diphosphate ribosylation and nitric oxide release. With the consequence of STZ action, pancreatic -cells are destroyed by necrosis. ${ }^{11}$

\section{Procedure}

Adult male Wistar rats should be maintained under controlled laboratory conditions at the temperature of $25 \pm 3^{\circ} \mathrm{C}$ with $60 \pm 15 \%$ humidity and $12 \mathrm{~h}$ dark/light cycle. Male wistar rats (160-240 gm) must be maintained on standard chow diet and water ad libitium. Streptozotocin $(60 \mathrm{mg} / \mathrm{kg})$ is administered by intravenous injection. Initially blood glucose increases to $150-200 \mathrm{mb} \%$ within three $\mathrm{h}$ after administration of streptozotocin. A phase of hypoglycemia occurs due to four-fold increase in serum insulin level, and this phase is followed by persistence hyperglycemia. ${ }^{12}$ In recent times a new animal model of Type 2 diabetes has been suggested by combining STZ and NAD in adult rats (160-240 gm).

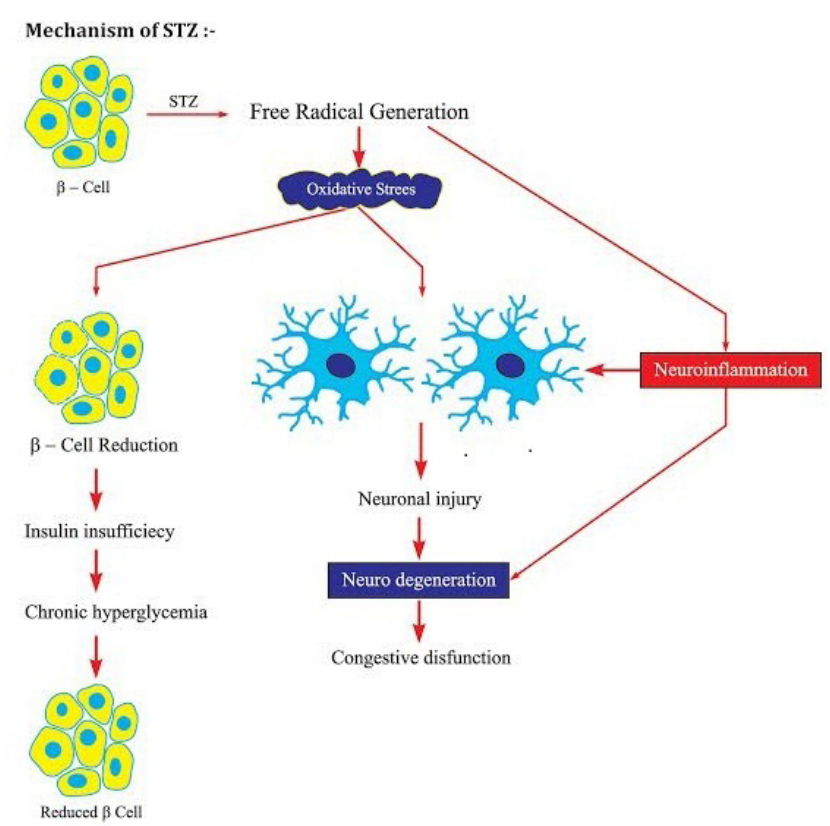

Figure 1: Mechanism of action of Streptozotocin.

The rats are injected NAD (230 mg/kg, ip) $15 \mathrm{~min}$ before STZ (65 mg/kg, iv) administration. With combining this it has shown evenhanded and stable nonfasting hyperglycemia without any significant change in insulin level. NAD is an antioxidant which exerts its defensive effect on the cytotoxic action of STZ by scavenging free radicals. ${ }^{13}$

\section{Alloxan model of diabetes mellitus}

Alloxan is also one of the used chemical for induction of diabetes mellitus. It is a famous diabetogenic agent extensively used to persuade Type 1 diabetes in animals. Alloxan is a urea derivative which causes selective necrosis of the pancreatic islet $\beta$-cells (Figure 2). This urea derivative is frequently used to create diabetes in animals such as rabbits, rats, mice and dogs. ${ }^{14}$

\section{Procedure}

1. In White New Zealand rabbits (2.5-4 kg), Alloxan monohydrate $(5 \mathrm{gm} / 100 \mathrm{ml}$, at $\mathrm{pH} 4.5)$ is infused via marginal ear vein in a dose of $150 \mathrm{mg} / \mathrm{kg}$ during a course of 10 mints. Following these injections $70 \%$ of the animals become hyperglycemic and uricosuric. ${ }^{15}$

2. In wistar or Sprague Dawley rats (150-200 gm), Alloxan monohydrate is injected subcutaneously with $100-175 \mathrm{mg} / \mathrm{kg} .{ }^{15}$

3. In male beagle dogs (15-20 gm), are injected intravenously with $60 / \mathrm{mg} / \mathrm{kg}$ of alloxan monohydrate. Subsequently they are administered $1000 \mathrm{ml}$ of $5 \%$ 
Invitro Model for Antidiabetic Activity :-

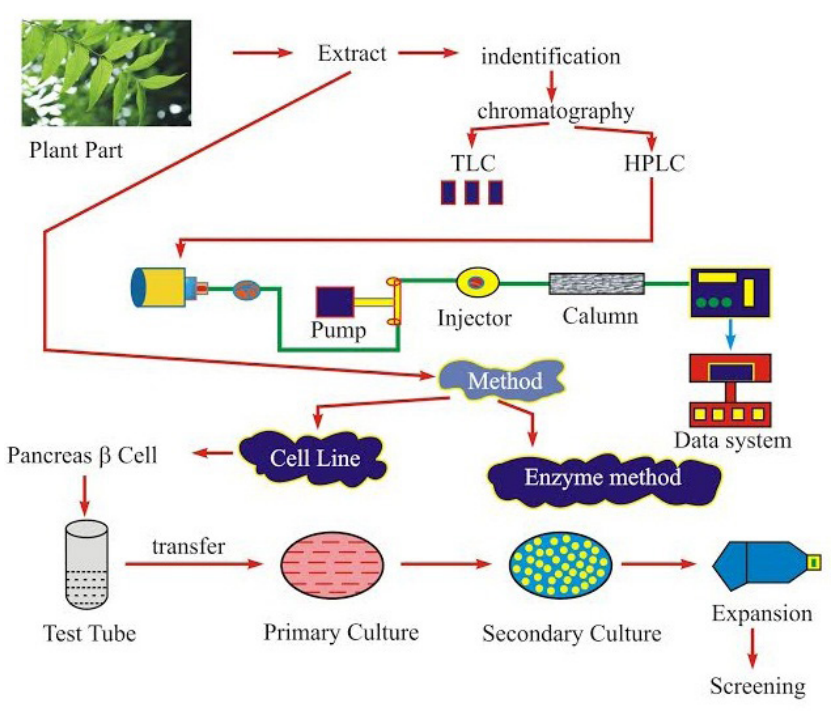

Graphical Abstract for Invitro Model for Antidiabetic Activity

Figure 2: Pictorial abstract of in vitro activity.

Invivo model for Antidiabetic Activity : -

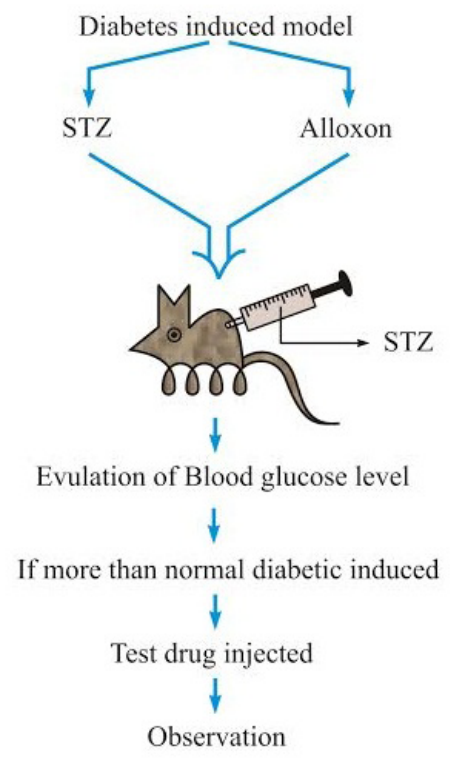

Graphical Abstract for Invivo Model for Antidiabetic Activity

Figure 3: Pictorial representation of in vivo activity.

glucose solution with $10 \mathrm{IU}$ of regular insulin i.v. for one week along with the canned food ad libitium. ${ }^{15}$

Alloxan induced diabetes serve as an important pathological bio model for testing a substance antidiabetic activity. The administration of Alloxan in animal models results in pancreatic lesion which is proportional to the dose of the drug injected.

\section{Dithizone induced diabetes}

Dithizone is an organo-sulfur compound, used in generation of diabetes in experimental animal's models. Administration of dithizone in animals causes the levels of zinc, iron, and potassium in the blood to increase more than normal. Dithizone, after permeating through membranes form a complex with zinc which causes release of protons thus, is providing diabetogenicity. ${ }^{16}$

\section{Procedure}

Injection of various chelators, such as dithizone, 8-(p-toluenesulfonylamino)-quinoline (8-TSQ), and 8- (benzenesulfanylamino)-quinoline (8-BSQ) in a single i.v. dose of $40-100 \mathrm{mg} / \mathrm{kg}$ to cats, rabbits, golden hamsters and mice induces type 2 diabetes. Dithizone injection causes a triphasic glycemic reaction in rabbits. Phases of initial hyperglycemia are detected after $2 \mathrm{~h}$, followed by a normoglycemic phase after $8 \mathrm{~h}$ and a secondary permanent hyperglycemic phase after 24-72 h. Histologically, complete and partial degranulation of beta cells is observed. ${ }^{15}$

\section{Monosodium glutamate induced diabetes}

Monosodium glutamate (MSG) increases glutamate concentration in plasma. MSG activates insulin release. MSG administration in mice results in obesity allied with increase in insulin level. It also causes increase in blood glucose, total cholesterol and triglyceride levels. ${ }^{17,18}$

\section{Procedure}

Adult male Wistar rats are maintained under controlled laboratory conditions at the temperature of $25 \pm 3^{\circ} \mathrm{C}$ with $60 \pm 15 \%$ humidity and $12 \mathrm{~h}$ dark/light cycle. All rats are fed ad libitum with a standard rat chow pellet and provided drinking water purified by reverse osmosis (RO), either with or without MSG. Eighty rats are randomly arrayed into four groups to be observed for1, 3, 6, or 9 months, with 20 rats in each group. Each group included control $(n=10)$ and MSG-treated $(n=10)$ rats. MSG-treated rats are supplemented with a commercially available 99\%-pure food-grade package of MSG added to daily drinking water at the final daily dose of $2 \mathrm{mg} / \mathrm{g}$ body weight. Food intake and body weight are recorded every one or two weeks, respectively, and rats from different groups were sacrificed at 1,3,6, or 9 months following a 12-hour fasting by intraperitoneal Nembutal injection. Blood and pancreatic tissue were collected for functional and morphological study. ${ }^{19}$

\section{Insulin antibodies induced diabetes}

The antibodies of insulin have greater affinity and ability to combine with insulin. The deficiency of insulin mechanism may enhance postprandial hyperglycemia. This 
happens because antibody-bound insulin is not available to tissues, and this causes prolongation of postprandial hyperinsulinemia which might leads to hyperglycemia. ${ }^{20}$

\section{Procedure}

Bovine insulin, dissolved in acidified water ( $\mathrm{pH}$ 3.0), is incorporated in a water-oil emulsion based on complete Freund's adjuvant or a mixture of paraffin oil and lanolin. A dose of $1 \mathrm{mg}$ insulin is injected in divided doses subcutaneously to male guinea pigs weighing 300-400 gm. Injections are given at monthly intervals and the guinea pigs are bled by cardiac puncture two weeks after the second and subsequent doses of antigen. It is possible to get $10 \mathrm{ml}$ blood from every animal once a month. Intravenous injection of $0.25-1.0 \mathrm{ml}$ guinea pig antinsulin serum to rats induces a dose-dependent increase of blood glucose reaching values up to $300 \mathrm{mg} \%$. This effect is unique to guinea pig anti-insulin serum and is due to neutralization by insulin antibodies of endogenous insulin secreted by the injected animal. In this way a state of insulin deficiency is induced. It persists if antibodies capable of reacting with insulin remain in the circulation. Slow rate intravenous infusion or intraperitoneal injection prolongs the effect for more than a few $\mathrm{h}$. However, large doses and prolonged administration accompanied by ketonemia, ketonuria, glucosuria, and acidosis are fatal to the animals. After lower doses, the diabetic syndrome is reversible after a few h..$^{21,22}$

\section{Ferric nitrilotriacetate induction of diabetes}

Parenteral administrations of daily dose of ferric nitrilotriacetate in experimental animals for 60 days noticeable diabetic symptoms are observed such as hyperglycemia, glycosuria, ketonemia and ketonuria. ${ }^{23}$

\section{Procedure}

Ferric nitrate is dissolved in $1.0 \mathrm{~N} \mathrm{HCI}$. To produce Fe3+-NTA solution, $162 \mathrm{ml}$ of a 0.14 ferric nitrate solution are added to $100 \mathrm{ml}$ of $0.08 \backslash 1$ disodium nitrilotriacetate solution, and the $\mathrm{pH}$ was adjusted to 7.4 with sodium bicarbonate powder under magnetic stirring.'-5,", The mixture was prepared immediately before use. ${ }^{24}$

A total of 224 inbred Wistar rats and 12 albino adult rabbits are used. The rats are divided into four major groups: Group I include animals treated with large doses of $\mathrm{Fe}^{3+}$ - NTA and their controls. Group II animals are used for examining hourly variations in serum iron levels after a single injection of Fe3+-NTA. Group III animals are used for assessing the effects of blood depletion after Fe3+-NTA overload. Group IV animals are used for observations of fibrotic changes in liver and pancreas after long-term, lethal injections of
Fe3+-NTA. Group I $(\mathrm{N}=120)$ rats are divided into four subgroups of 30 each: Group Ia rats receives daily intraperitoneal (i.p.) injections of Fe3+-NTA in the following sequence: $0.2 \mathrm{mg} \mathrm{Fe} / 100 \mathrm{~g}$ body weight daily for 3 weeks, $0.6 \mathrm{mg} \mathrm{Fe} / 100 \mathrm{~g}$ body weight daily for the next 3 weeks, and $1.0 \mathrm{mg} \mathrm{Fe} / 100 \mathrm{~g}$ body weight daily for the remaining 2 months. The total amount of iron administered to each animal was approximately $200 \mathrm{mg}$. Group Ib rats are injected i.p. for the same duration with the same concentration of disodium nitrilotriacetic acid (Na2-NTA) as Group Ia animals (NTA controls). Group Ic animals receives equivalent injections of iron in colloid form (ferric hydroxide chondroitin sulfate colloid), as Group Ia animals. Group Id rats were untreated controls. Blood and urinary glucose and ketones were measured once weekly. After manifestation of glucosuria, urinary glucose is measured twice weekly in the morning. Animal body weight is measured twice weekly. Histological studies are conducted after sacrifice. Group II rats $(\mathrm{N}=56)$ receives one i.p. injection of Fe3+-NTA at $1.0 \mathrm{mg} \mathrm{Fe} / 100 \mathrm{~g}$ body weight. Blood are collected from the frontal orbital sinus at different intervals after injection. Serum iron concentration and the total iron-binding capacity are measured. Group III rats $(\mathrm{N}=24)$ should receive daily Fe3+-NTA injections in the same schedule as Group Ia animals. After 2 months of iron loading, $2 \mathrm{ml}$ of blood are withdrawn from the frontal orbital sinus once weekly for 4 weeks. Blood and urinary sugar are measured twice weekly. At 5 weeks after termination of Fe3+-NTA treatment, the animals are killed. Histochemical investigations of organ iron and beta-granules in pancreatic islet cells are performed. Group IV rats $(\mathrm{N}=24)$ receives daily injections of Fe3+-NTA by extending the schedule of Group IA animals until death. Histological observations are conducted on the tissue for cirrhotic changes. ${ }^{25,26}$

\section{Goldthioglucose obese diabetic mouse model}

Gold thioglucose (GTG) is a diabetic inducing compound, which causes obesity induced Type -2 diabetes. Intraperitoneally administration GTG in experimental animal gradually develops obesity, hyperinsulinemia, and hyperglycemia. The GTG is transported to a cell and causes necrotic lesions, conscientious for the growth of hyperphagia and obesity. GTC also increases hepatic lipogenesis, body lipid content, and triglyceride secretion..$^{27,28}$

\section{Procedure}

Swiss albino mice of either sex is fed with commercial mouse chow ad libitium. At the age of six weeks, the 
animals receive a single intraperitoneal injection of $30-40 \mathrm{mg} / \mathrm{kg}$ Gold thioglucose. Food intake is registered for 2 weeks and body weight for a period 3 month and compared with untreated controls..$^{15}$

\section{Virus Induced Diabetes}

Diabetes mellitus produced by viruses is mainly by destroying and infecting pancreatic beta cells. Many human viruses have been used for inducing diabetes like Mengo-2T, reovirus, Coxackie B4, RNA picornaviruses, encephalomyocarditis (EMC-D and M variants) and lymphocytic choriomeningitis. ${ }^{29,30}$

\section{Coxsackie viruses}

In mice Coxsackie viruses also cause diabetes by destroying pancreatic acinar cells. Coxsackie B4 virus is sturdily connected with the progress of insulin-dependent diabetes mellitus in humans. Diabetes caused by the infection with Coxsackie virus triggers the discharge of sequestered islet antigen ensuing in the re- stimulation of auto reactive $\mathrm{T}$ cells. ${ }^{31,32}$

\section{Spontaneous Diabetic Obese Rodent Models Ob/ob mouse}

Leptin deficiency in mouse strain ob/ob, due to mutation in leptin gene leads to severe insulin resistance. The strain ob/ob shows rapid gain in body weight, insulin resistance and hyperinsulinemia. In the ob/ob model, hyperinsulinemia occurs at 3 to 4 weeks of age simultaneously with insulin resistance and hyperphagia. The sign of Type $2 \mathrm{DM}$ of ob/ob mice increases with age with continuous decline in plasma insulin levels. ${ }^{33,34}$

\section{$d b / d b$ mouse}

The mutation of $\mathrm{db}$ gene occurs impulsively in the leptin-receptor deficient C57BL/KsJ mice. The strain is originally derived from mutation on chromosome number $4 .{ }^{35}$ The $\mathrm{db} / \mathrm{db}$ mouse acquires hyperphagic, hyperinsulinemia, and insulin resistant conditions within 2 weeks of age. The obesity develops at the age of 3 to 4 weeks with development of hyperglycemia at the age of 4 to 8 weeks. ${ }^{36}$ The $\mathrm{db} / \mathrm{db}$ mouse are used to study micro vascular diabetic and renal complications. ${ }^{37,38}$

\section{Kuo Kondo mouse}

The Kuo Kondo (KK) mouse is model of obesity and Type 2DM. ${ }^{39} \mathrm{KK}$ mouse instinctively exhibits diverse hyperglycemia, hyperinsulinemia, and adiposity..$^{40}$ At the age of 2 months, the KK mouse acquires obesity due to insulin resistance, compensatory hyperinsulinemia and hyperphagic. The insulin resistance and hyperin- sulinemia have been reported to reach the peak at 5 months. ${ }^{41}$

\section{Zucker Diabetic Fatty (ZDF) rat}

The Zucker diabetic fatty (ZDF) rats are more insulin resistant, less obese, and quickly development to diabetes due to lack of adequate insulin secretion. ${ }^{42}$ The male ZDF rat develops fully diabetic conditions at 12 weeks. The serum insulin levels normally reach the peak at about 7 to 10 weeks. ${ }^{43}$

\section{Otsuka Long-Evans Tokushima Fatty (OLETF) rat}

The OLETF rat acquires hyperglycemia at around age of 18 to 25. An OLETF rat develops obesity, hyperinsulinemia, hyperglycemia, hypercholesterolemia, hypertriglyceridemia and beginning of diabetes like human Type 2DM. Many recessive genes on numerous chromosomes together with the $\mathrm{X}$ chromosome are concerned in the induction of diabetes in OLETF rats. ${ }^{44,45}$

\section{Cohen diabetic rat}

It is a genetic model resulting from diet-induced Type $2 \mathrm{DM}$ model by introducing the rat on a synthetic $72 \%$ sucrose copper-poor diet for 2 months. The symptoms include insulin resistance, hyperinsulinemia, and nonobesity. The Cohen diabetic rat expresses genetic receptiveness to a carbohydrate-rich diet which is a feature of Type 2 DM in human. ${ }^{46}$

\section{Surgical models of diabetes mellitus}

This technique uses complete removal of panaceas to induce diabetes. Mostly, this model had been employed in the last years on animal species such as rats, pigs, dogs and primates to explore effects of natural products. ${ }^{47,48}$ There are several disadvantages to this technique including (1) good technical expertise and proper surgical room atmosphere, (2) good hands on major surgery and high menace of animal contagion, (3) proper post-operative analgesia and antibiotic administration, (4) addition of pancreatic enzymes in the diet to prevent malabsorption. ${ }^{49}$

\section{Genetic models of diabetes}

\section{Spontaneously develop diabetic rat}

These models allow the evaluation of antidiabetic effect of a natural product in an animal without the meddling of adverse effect induced by drugs like alloxan and Streptozotocin. An example for this is spontaneously diabetic Goto-Kakizaki rat, is a genetic lean model of type1 diabetes evolving from careful breeding over many generations of glucose-intolerant diabetic wistar rats. ${ }^{50}$ Concerning type1 diabetes models, the mouse characteristically generates hyperglycemia between 12 and 30 weeks of age, whereas in BB rats it occurs around 
12 weeks of age. One of great benefit of these models is that they can be used as model of atherosclerosis which generally represents the enduring impediment of diabetes mellitus. ${ }^{51}$

\section{Genetically engineered diabetic mice}

There is a significant advancement in the field in recent years, especially with the advent of transgenic mice. In this case, rodents may be evolved to over (transgenic) or under (knockout) - express proteins considering playing a key part in glucose metabolism. ${ }^{52,53}$ Presently there have been no protocols carried out concerning natural products and these models. Possibly, the high costs limit their study in complicated protocols which explore mechanisms of potential beneficial agents. ${ }^{54}$

\section{In-vitro methods}

\section{Assay of amylase inhibition}

$600 \mu \mathrm{l}$ of $(10,20,40,60,80,100 \mu \mathrm{g} / \mathrm{ml})$ test sample, $1.2 \mathrm{ml}$ of starch in phosphate buffer $(\mathrm{pH} 6.9)$ containing $6.7 \mathrm{mM}$ of sodium chloride are added. The reaction is initiated by adding $600 \mu \mathrm{l}$ porcine pancreatic amylase and incubated at $37^{\circ} \mathrm{c}$. From the above mixture $600 \mu \mathrm{l}$ is taken and $300 \mu \mathrm{l}$ of DNSA (1 $\mathrm{g}$ of DNSA, 30g of sodium potassium tartarate and $20 \mathrm{~mL}$ of $2 \mathrm{~N}$ sodium hydroxide was added and made up to a final volume of $100 \mathrm{~mL}$ with distilled water) and is kept in a boiling water bath for $15 \mathrm{~min}$. The reaction mixture diluted with $2.7 \mathrm{ml}$ of water and absorbance is read at $540 \mathrm{~nm}$. For each concentration, blank tubes are prepared by replacing the enzyme solution with $600 \mu \mathrm{L}$ in distilled water. Control, representing $100 \%$ enzyme activities are prepared in a similar manner, without test sample. The experiments are repeated thrice using the same protocol. ${ }^{55}$

The $\alpha$-amylase inhibitory activity was calculated by using the formula

$$
\begin{gathered}
\text { Abs540 nm (Control })- \\
\text { Inhibition } \%=\frac{\text { Abs540 } \mathrm{nm}(\text { drug sample })}{\text { Abs540nm }(\text { control })} \times 100
\end{gathered}
$$

\section{Inhibition of $\alpha$-glucosidase activity Method A}

Enzyme solution is prepared by dissolving $0.5 \mathrm{mg} \alpha$ glycosidase in $10 \mathrm{ml}$ phosphate buffer ( $\mathrm{pH}$ 7.0) containing $20 \mathrm{mg}$ bovine serum albumin. The solution is further diluted in the ratio of 1:10 with phosphate buffer. Sample solution should be prepared by dissolving $4 \mathrm{mg}$ sample in $400 \mu \mathrm{l}$ dimethyl sulfoxide (DMSO) and was referred as sample blank. Five concentrations 50, 100, 150,200 , and $250 \mu \mathrm{ml}$ are prepared. To each $5 \mu \mathrm{ml}$ of the sample solution and DMSO add P- nitro phenyl-
$\alpha$-D- glucopyranoside with phosphate buffer (ph7.0). The solutions are incubated at $37{ }^{\circ} \mathrm{C}$ for $15 \mathrm{~min}$. After 15 min add $\mathrm{Na}_{2} \mathrm{CO}_{3}(1000 \mu \mathrm{l})$ solution. Absorbance of the sample against sample blank is measured at $400 \mathrm{~nm}$ using UV visible spectrophotometer. ${ }^{56}$

\section{The inhibition activity is calculated according to the formula}

$$
\% \text { inhibition }=\frac{\mathrm{Ec}-(\mathrm{ET}-\mathrm{EC})}{\mathrm{EC}} \times 100
$$

\section{Method B}

$200 \mu$ of alpha glucosidase enzyme solution was prepared and preincubated with different concentration of the test and standard drug solution for $5 \mathrm{~min}$. To all the test tubes $200 \mu \mathrm{l}$ of $37 \mathrm{~m} \mathrm{M}$ sucrose are added. All the tubes were incubated for 30 mints at $37^{\circ} \mathrm{C}$ to allow the enzymatic action and drug action. After $30 \mathrm{~min}$ the tubes are taken out from the incubator and heated at $100^{\circ} \mathrm{C}$ for $10 \mathrm{~min}$. The liberated glucose is determined by glucose oxidase peroxidase (GOD-POD) method at $546 \mathrm{~nm}$ and calculating with relative blank control. ${ }^{57}$

\section{The alpha glucose inhibitory activities of the test drug are calculated as}

$$
\% \alpha \text { glusidase inhibition }=\frac{\text { Absorbance }(\text { Blank })-}{\text { Absorbance }(\text { test } / \text { standard })} \times 100
$$

\section{In-vitro studies on insulin secretion}

Antidiabetic agents can influence many pathways of glucose metabolism such as insulin discharge, glucose uptake by target organs as well as nutrient absorption. Recently, in vitro studies were carried out considering incretins ${ }^{58}$ and transcription factors such as peroxisome proliferators activated receptors. PPAR are targets of modern therapy. Insulin receptor, glucose transporters, on the other hand, has not been yet the target of antidiabetic therapy. There are few studies revealing the use of natural products has been published. . $^{59,60}$

\section{Studies using insulin-secreting cell lines}

Development in Bioengineering technologies have given various new methods to develop and create more suitable cultured cell lines to assist studies of mechanisms of both insulin secretion and cell dysfunction. The most extensively used insulin-secreting cell lines are beta-TC, RIN, HIT, MIN6 and INS-1 cells. These cell lines liberate mainly insulin, small amounts of glucagon and somatostatin. The actions of these cell lines never completely reduce primary cell physiology but, they are 
tremendously precious tools for the study of molecular proceedings underlying cell function. ${ }^{61}$

\section{Studies using isolated pancreatic islet cell lines}

The pathway which is responsible for diabetes can be studied with isolated pancreatic $\beta$-cells from either control or transference of these beta cells to appropriated culture medium. It is a well-known phenomenon that insulin emission occurs when pancreatic cells make use of glucose to create adenosine triphosphate (ATP) from adenosine diphosphate (ADP). ${ }^{62}$ The raise in cytoplasmic ATP/ADP ratio closes ATP-sensitive potassium channels, causing depolarization of the plasma membrane, which activates voltage dependent $\mathrm{Ca}^{2+}$ channels. This results in rise of intracellular $\mathrm{Ca}^{2+}$ level which initiates insulin secretion. In type 2 diabetes, pancreatic cells show uncharacteristic ion channel activity and an atypical pattern of insulin secretion. These pathways can be depicted with isolated pancreatic cells from either control or diabetic rat or mouse that can be obtained by collagenase digestion technique, followed by adequate separation and transference to appropriated culture medium..$^{63,64}$

\section{In-vitro studies on glucose uptake}

The main key link between obesity and Type 2 diabetes is adipose tissue because it promotes the progress of lip toxicity, i.e. cell destruction because of prominent intracellular lipid concentrations and insulin resistance. The resistance of insulin either at the adipocytes or skeletal muscle levels causes hyperglycemia. However, adipocytes located on different sites of the body may have diverse biological or pathological effects. Insulin resistance pathways may be studied in cell lines of adipocytes such as marine 3T3-L1 cells and rat L6 muscle engineered to over-express GLUT4. ${ }^{65,66}$

\section{CONCLUSION}

In this review an emphasis had been made to cover all in-vivo models and in-vitro techniques for the researcher who is seeking their research work in diabetes. In-vitro models had been described on the basis that animal's models have near about same characteristics features as human diabetes. Each model mentioned above are necessary tools for researching about endocrine physiology, metabolic changes and genetic changes involved in mechanism of occurrence of diabetes in human. More emphasis should be made on development of newer in vitro techniques for the evaluation and treatment of diabetes. In vitro methods used now days may be costly, but the result assessed through them confers the exact mechanism of diabetes occurrence. Still, more animal models and software based study should be developed for more advancement in diabetes research.

\section{CONFLICT OF INTEREST}

The author declares no conflict of interest.

\section{ACKNOWLEDGEMENT}

Authors are thankful to Columbia Institute of Pharmacy, Raipur, and C.G. for providing all the necessary tools and source for writing this review.

\section{ABBREVIATIONS USED}

STZ: Streptozotocin; DNA: Deoxyribonucleic acid; Glut-2: Glutamate 2 receptor; NAD: Nicotinamide; MSG: Monosodium glutamate; GTC: Goldthioglucose; EMC-D: Encephalomylocarditis; KK: Kuo Kondo Mice; ZDF: Zuker Dibetic fatty rats.

\section{REFERENCES}

1. Pathirage KP, Yunman L. Functional herbal food ingredients used in type 2 diabetes mellitus. Pharmacognosy review. 2012;6(11):37-45.

2. Orhan N, Aslan M, Hosbas S, Deliorman OD. Antidiabetic Effect and Antioxidant Potential of Rosa canina Fruits. Pharmacognosy Mag. 2009;5(20):309-15.

3. Hilaly E, Lyoussi B. Hypoglycemic effect of the lyophilized aqueous extract of Ajuga iva in normal and streptozotocin diabetic rats. Journal of Ethnopharmacology. 2002;80(2):109-13.

4. Galani VJ, Vyas M. In vivo and In vitro Drug Interactions Study of Glimepride with Atorvastatin and Rosuvastatin. J Young Pharm. 2010;2(2):196-200.

5. Kumar S, Narwal S, Kumar V, Prakash O. a-glucosidase inhibitors from plants: A natural approach to treat diabetes. Pharmacognosy Rev. 2011;5(9):19-29.

6. American Diabetes Association. Diagnosis and Classification of Diabetes Mellitus. Diabetes Care. 2009;32:562-7.

7. Karthikeyan M, Balasubramanian T, Kumar P. In-vivo Animal Models and In-vitro Techniques for Screening Antidiabetic Activity. J Develop Drugs. 2016;5(2):1-6.

8. Kumar S, Singh R, Vasudeva N, Sharma S. Acute and chronic animal models for the evaluation of anti-diabetic agents. Cardiovasc Diabetology. 2012;11(1):1-9.

9. Etuk EU. Animals models for studying diabetes mellitus. Agric Biology J N Am. 2010;1(2):130-4.

10. Adam Z, Khamis S, Ismail A, Hamid M. Ficus deltoidea: A Potential Alternative Medicine for Diabetes Mellitus. Evidence-Based Complementary and Alternative Medicine. 2012;2012:1-12.

11. Krisanapun C, Peungvicha P, Temsiririrkkul R, Wongkrajang Y. Aqueous Extract of Abutilon indicum Sweet Inhibits Glucose Absorption and Stimulates Insulin Secretion in Rodents. Nutrition Res. 2009;29(8):579-87.

12. Ramakrishnan P, Ramadoss D, Muthulingam P, Nedunchezhian R, Krishnamoorthy K. Antidiabetic, Antihyperlipidemic, Antioxidant Property of Cordia obliqua on Streptozotocin Induced Diabetic Rats. Journal of Young Pharmacists. 2017;9(3):321-6.

13. Ghasemi AS Khalifi S, Jedi S Streptozotocin-nicotinamide-induced rat model of type 2 diabetes. Acta Physiological Hungarica. 2014;101(4):408-20.

14. Ravichandra VD, Paarakh PM. Evaluation of anti-diabetic potentials of methanolic extract of ficus microcarpa leaves in alloxan induced diabetic rats. Inter J Pharm Pharma Sci. 2013;5(3):369-70.

15. Drug Discovery and Evaluation: Pharmacological assays. $3^{\text {rd }}$ edition. New York: Springer. Hans Gerhard Vogel. 2008.

16. Lei YC, Hwang JS, Chan CC, Lee CT, Cheng TJ. An Enhanced oxidative stress and endothelial dysfunction in streptozotocin-diabetic rats exposed to fine particles. Environmental Research. 2005;99(3):335-43.

17. Yu WJ, Juang SW, Chin WT, Chi TC, Chang CJ, Cheng JT. Insulin restores neuronal nitric oxide synthase expression in streptozotocin induced diabetic rats. Life Science. 2000;68(6):625- 34. 
18. Masiello P, Broca C, Gross R, Roye M, Manteghetti M, HillaireBuys D, et al. Experimental NIDDM: development of a new model in adult rats administered streptozotocin and nicotinamide. Diabetes.1998;47(2):224-9.

19. Viana GS, Medeiros AC, Lacerda AM, Leal LK, Vale TG, Matos FJ. Hypoglycemic and anti-lipemic effects of the aqueous extract from Cissus sicyoides. Bio Med Central Pharmacology. 2004;4(1):9.

20. Antia BS, Okokon JE, Okon PA. Hypoglycemic effect of aqueous leaf extract of Persea Americana (Mill) on alloxan induced diabetic rats. Indian J pharmacology. 2005;37(5):325-6.

21. McNeill JH. Experimental models of diabetes. Informa health care. 1990;22:10-8.

22. Graham TE, Sgro V, Friars D, Gibala MJ. Glutamate ingestion: the plasma and muscle free amino acid pools of resting humans. Am J Physiology Endocrinol Metab.2000;278(1):E83-9.

23. Nagata M, Suzuki W, lizuka S, Miyamoto K. Type 2 Diabetes Mellitus in Obese Mouse Model Induced by Monosodium Glutamate. Experimental Animals. 2006;55(2):109-15.

24. Nakajima H, Tochino $\mathrm{Y}$, Fujino-Kurihara $\mathrm{H}$, Yamada $\mathrm{K}$, Gomi M, et al. Decreased incidence of diabetes mellitus by monosodium glutamate in the non-obese diabetic (NOD) mouse. Res Communications Chemical Pathology Pharmacology. 1985;50(2):251-7.

25. Kim MR, Sheeler LR, Mansharamani N, Haug MT, Faiman C, et al. Insulin antibodies and hypoglycemia in diabetic patients. Can a quantitative analysis of antibody binding predict the risk of hypoglycemia? Endocrine. 1997;6(2):285-91.

26. Jin OC, Dong HC, Chung DJ, Chung MY. Spontaneous hypoglycemia due to Insulin antibody after Insulin treatment of Diabetic Ketoacidosis. Endocrinol Metabolism. 2010;25(3):217-20.

27. Moloney PJ, Coval M. Antigenicity of insulin: diabetes induced by specific antibodies. Biochemical journal. 1955;59(2):179-85.

28. Experimental insulin-deficiency due to insulin antibodies. In: Pfeiffer EF (ed) Handbook of Diabetes mellitus, Pathophysiology and Clinical Considerations. Lehmanns Verlag, Munchen.1968;1:841-65

29. Haeften TW, Bolli GB, Dimitriadis GD, Gottesman IS, Horwitz DL, et al. Effect of insulin antibodies and their kinetic characteristics on plasma free insulin dynamics in patients with diabetes mellitus. Metabolism. 1986;35(7):649-56.

30. Awai M, Narasaki M, Yamanoi Y, Seno S. Induction of Diabetes in Animals by Parenteral Administration of Ferric Nitrilotriacetate. American Journal of Pathology. 1979;95(3):663-73.

31. Awai M, Narasaki M, Yamanoi $Y$, Seno $S$. Induction of diabetes in animals by parenteral administration of ferric nitrilotriacetate. A model of experimental hemochromatosis. Am J Pathology. 1979;95(3):663-73.

32. Le Marchand BY. Molecular mechanisms of insulin action in normal and insulinresistant states. Experimental Clinical Endocrinol Diabetes. 1999;107(2):126-32.

33. Szopa TM, Titchener PA, Portwood ND, Taylor KW. Diabetes mellitus due to viruses--some recent developments. Diabetologia.1993;36(8):687-95.

34. Jaidane H, Hober D. Role of coxsackievirus B4 in the pathogenesis of type 1 diabetes. Diabetes Metabolism. 2008;34(6):537-48.

35. Yoon JW, McClintock PR, Onodera T, Notkins AL. Virus-induced diabetes mellitus. XVIII. Inhibition by a non-diabetogenic variant of encephalomyocarditis virus. The Journal of experimental medicine. 1980;152(4):878-92.

36. Utsugi T, Kanda T, Tajima Y, Tomono S, Suzuki T, et al. A new animal model of non-insulin-dependent diabetes mellitus induced by the NDK25 variant of encephalomyocarditis virus. Diabetes research. 1992;20(4):109-19.

37. Campbell J, Chaikof L, Davidson IW. Met hypophyseal diabetes produced by growth hormone. Endocrinology. 1954;54(1):48-58.

38. Heather A, Ferris C, Kahn R. New mechanisms of glucocorticoidsinduced insulin resistance: make no bones about it. J Clinical Invest. 2012;122(11):3854-7.

39. Elmquist JK, Maratos FE, Saper CB, Flier JS. Unraveling the central nervous system pathways underlying responses to leptin. Nat Neuroscience. 1998;1(6):445-50.

40. Shafrir E. Animal models of non-insulin-dependent diabetes. Diabetes Metabolism Rev. 1992;8(3):179-208.

41. Coleman DL. Obese and diabetes: two mutant genes causing diabetesobesity syndromes in mice. Diabetologia. 1978;14(3):141-8.
42. Bates SH, Kulkarni RN, Seifert M, Myers MG. Roles for leptin receptor/ STAT3-dependent and -independent signals in the regulation of glucose homeostasis. Cell Metabolism. 2005;1(3):169-78.

43. Lee SM. Experimental diabetic nephropathy in the $\mathrm{db} / \mathrm{db}$ mouse. Dietary and Pharmacologic Therapy. 1984;1:419-24.

44. Bohlen HG, Niggl BA. Arteriolar anatomical and functional abnormalities in juvenile mice with genetic or streptozotocin-induced diabetes mellitus. Circulation Res. 1979;45(3):390-6.

45. Nakamura M, Yamada K. Studies on a diabetic (KK) strain of the mouse. Diabetologia. 1967;3(2):212-21.

46. Kondo K, Nozawa K, Tomita T, Ezaki K. Inbred strains resulting from Japanese mice. Bulletin of the Experimental Animals. 1957;6:107-12.

47. Ikeda H. KK mouse. Diabetes Res Clinical Practice. 1994;24Suppl:S313-6.

48. Etgen GJ, Oldham BA. Profiling of Zucker diabetic fatty rats in their progression to the overt diabetic state. Metabolism. 2000;49(5):684-8.

49. Peterson RG, Neel MA, Little LA, Kincaid JC, Eichberg J. Zucker diabetic fatty as a model for non-insulin-dependent diabetes mellitus. ILAR News. 1990;32(3):16-9.

50. Subrahmanyam K. Metabolism in the New Zealand strain of obese mice. Biochemical J. 1960;76(3):548-56.

51. Thorburn W, Holdsworth A, Proietto J, Morahan G. Differential and genetically separable associations of leptin with obesity-related traits. International Journal of Obesity. 2000;24(6):742-50.

52. Ueda H, Ikegami H, Yamato E, Fu J, Fukuda M, et al. The NSY mouse: a new animal model of spontaneous NIDDM with moderate obesity. Diabetologia. 1995;38(5):503-8.

53. Hirayama I, Yi Z, Izumi S, Arai I, Suzuki W, et al. Genetic analysis of obese diabetes in the TSOD mouse. Diabetes. 1999;48(5):1183-91.

54. Miao G, Ito T, Uchikoshi F, Tanemura M, Kawamoto K, et al. Development of islet-like cell clusters after pancreas transplantation in the spontaneously diabetic Torri rat. Am J Transplant. 2005;5(10):2360-7.

55. Choi SB, Park CH, Choi MK, Jun DW, Park S. Improvement of insulin resistance and insulin secretion by water extracts of Cordyceps militaris, Phellinus linteus, and Paecilomyces tenuipes in $90 \%$ pancreatectomized rats. Bioscience, Biotechnology, and Biochemistry. 2004;68:2257- 64.

56. Masiello P. Animal models of type- 2 diabetes with reduced pancreatic cell mass. The International. Journal of Biochemistry and Cell Biology. 2006;38(5):873-93.

57. Chen D, Wang MW. Development and application of rodent models for type11 diabetes. Diabetes, Obesity and metabolism. 2005;7(4):307-17.

58. Wu KK, Huan Y. Diabetic atherosclerosis mouse models. Atherosclerosis. 2007;191(2):241-9.

59. Herrath MG, Oldstone M. Interferongama is essential for destruction of beta cells and development of insulin-dependent diabetes mellitus. The Journal of Experimental medicine. 1997;185(3):531-539.

60. Ali $\mathrm{H}$, Houghton PJ, Soumyanath A. $\alpha$ - Amylase inhibitory activity of some Malaysian plants used to treat diabetes; with reference to phyllanthus amarus. Journal of ethnopharmacology. 2006;107:449-55.

61. Nair SS, Kavrekar V, Mishra A. In vitro studies on alpha amylase and alpha glucosidase inhibitory activities of selected plant extracts. European journal of experimental biology. 2013;3(1):128-32

62. Sinha $D$, et al. Recent status on carbohydrate metabolizing enzyme inhibitors in regulation of diabetes: A mechanism based review. Journal of applied pharmaceutical research. 2015;3(2):1-7.

63. Zhao YF, Keating DJ, Hernandez M, Feng DD, Zhu Y. Long-term inhibition of protein tyrosine kinase impairs electrophysiology activity and a rapid component of exocytosis in pancreatic cells. Journal of Molecular Endocrinology. 2005;35(1):49-59.

64. Nakamura M, Yamada K. Studies on a diabetic (KK) strain of the mouse. Diabetology. 1967; 3(2):212-21.

65. Storling J, Zaitsev SV. A Calcium has a permissive role in interleukin-1 induced c-jun $\mathrm{N}$-terminal kinase activation in insulin-secreting cells. Endocrinology. 2005;146(7):3026-36.

66. Poitout V, Olson LK, Robertson RP. Insulin-secreting cell lines: classification, characteristics and potential applications. Diabetes Metabolism. 1996;22(1):7-14. 

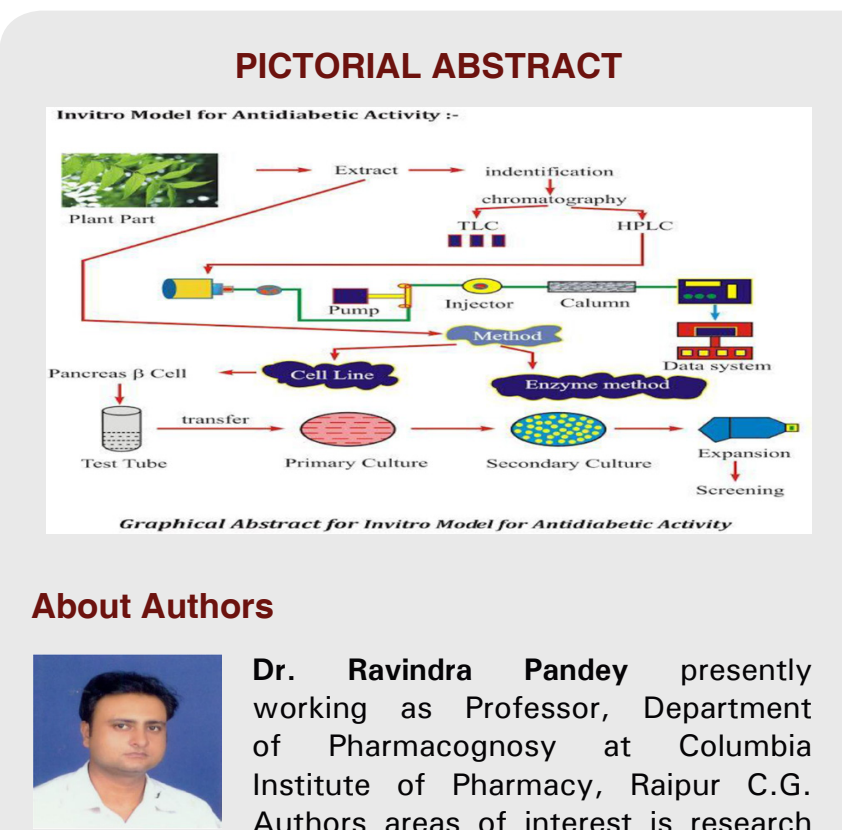

Dr. Ravindra Pandey presently working as Professor, Department of Pharmacognosy at Columbia Institute of Pharmacy, Raipur C.G. Authors areas of interest is research activities in conventional medicine system, standardization and chemical fingerprinting method development of Ayurvedic and Herbal Formulation.

\section{SUMMARY}

- In world about $90 \%$ of diabetes patients are of Type 2 diabetes. Diabetic study on different animal models is therefore, significantly of use in biomedical research as they offer new insights to diabetes. There are several experimental diabetes methods that include: diabetes on genetically modified animals, chemical and surgical. Screening of new drug requires an appropriate animal model and other environmental condition for treatment of diabetes. In-vivo studies mainly includes induction of diabetes with the use of chemicals such as streptozotocin, alloxan, Dithizone, monosodium glutamate etc. Similarly, various in vitro methods are also available which provides more accurate and precise result for the screening of antidiabetic drug. Now days, newer models such as virus induced diabetes, spontaneous diabetic obese rodent models, genetic model etc. are also being incorporated for the induction of diabetes and screening of new antidiabetic drugs. The selection of particular animal model particularly depends upon the investigators choice whether to use inbred or out bred, availability of particular strain, aim of scientific strategy, type of drug being sought, institutional financial and facility resources in the Type 2 diabetes research and pharmaceutical drug discovery and development programme.

Cite this article: Dewangan H, Tiwari RK, Sharma V, Shukla SS, Satapathy T, Pandey R. Past and Future of in-vitro and in-vivo Animal Models for Diabetes: A Review. Indian Journal of Pharmaceutical Education and Research. 2017;51(4S):S522-S30. 